Revista de Dialectología y Tradiciones Populares, vol. LXVII, n. ${ }^{\circ}$ 1, pp. 209-240, enero-junio 2012, ISSN: 0034-7981, eISSN: 1988-8457, doi: $10.3989 /$ rdtp. 2012.08

\title{
El poder sobre el cuerpo y el poder del cuerpo religioso: dos casos para la comparación
}

\author{
Power over the Body \\ and the Power of the Religious Body: \\ A Comparison of Two Cases
}

Jaume Vallverdú Vallverdú

Universitat Rovira i Virgili. Tarragona

\section{RESUMEN}

En este artículo se retoman dos conceptos teóricos básicos: el cuerpo político y las técnicas corporales vinculadas a las prácticas religiosas. A partir de aquí, se pretende reflexionar comparativamente sobre dos sistemas religiosos: el representado por el movimiento Hare Krisna, doctrinalmente vinculado a la escuela vaisnava devocional, dentro de la antigua tradición hindú, y el Pentecostalismo como variante carismática en el seno de la gran tradición protestante. Se propone, a tal fin, un marco teórico de corte estructural y constructivista que privilegia el control material-racional de la experiencia subjetiva y determina dicha experiencia en los niveles ideológicos, simbólicos y normativos relacionados con el cuerpo y con su expresión en el interior de uno y otro sistema.

Palabras clave: Hare Krisna, Pentecostalismo, Habitus, Cuerpo político, Técnicas corporales.

\section{SUMMARY}

Through a comparative analysis of two religious systems - the Hare Krishna movement doctrinally linked to the Vaishnava school of devotional Hinduism, and Pentecostalism as a charismatic variation of the great tradition of Protestant Christianity - this article focuses on two basic theoretical concepts: the political body and techniques of the body in the context of religious practice. It is argued that a useful approach to both religious systems is a structural and constructivist analytic framework that privileges the role of material-rational control of subjective experience on three levels -ideological, symbolic and normative - in relation to the body and bodily expression.

Key words: Hare Krishna Movement, Pentecostalism, Habitus, Political Body, Techniques of the Body. 
Por todas partes en donde existe poder, el poder se ejerce. Nadie, hablando con propiedad, es el titular de él; y, sin embargo, se ejerce siempre en una determinada dirección, con los unos de una parte y los otros de otra; no se sabe quién lo tiene exactamente; pero se sabe quién no lo tiene [...] Hay que edificar la arqueología de las ciencias humanas en el estudio de los mecanismos de poder que se han incardinado en los cuerpos, en los gestos, en los comportamientos (Foucault 1992: 83-84; 109).

Quiero retomar como base de este texto algunos modelos y conceptos teóricos previamente desarrollados en relación al vínculo entre cuerpo y religión (Cf. Vallverdú 2009a; 2009b; 2010). A partir de ellos intentaré delinear ciertos niveles de análisis comparativo entre dos sistemas religiosos, el propio del movimiento Hare Krisna y el evangélico-pentecostal, poniendo el foco en sus respectivas prácticas religiosas tal como vienen definidas, mediadas y moduladas por sus doctrinas e ideologías respecto al cuerpo y al comportamiento corporal. En ambos sistemas, el primero con una representación asociativa-institucional concreta y el segundo con un abanico complejo de variantes en su interior, la gestión ideológica y simbólica del cuerpo es un aspecto fundamental para comprender, tanto las dinámicas organizativas y comunitarias en su concreción particular, como los procesos de integración, compromiso y construcción de identidad.

Esta cuestión se marca de forma especial tras el paso decisivo de la conversión y la autoreconocida transformación personal-identitaria de los sujetos, que, desde ese momento, asumen una significativa elevación de estatus: con parecido fervor, unos aceptan convertirse en "devotos" o "devotas" de Krisna, otros en "hermanos" o "hermanas" pentecostales ${ }^{1}$. Apelando a un emotivo "renacimiento espiritual", unos y otros sienten y agradecen dejar atrás un pasado insatisfactorio para empezar un nuevo camino de virtud y salvación, y comienzan a usar analogías cotidianas o religiosas diversas para explicar ese cambio. Un miembro de Hare Krisna, por ejemplo, me transmitió el abandono del mundo vivido con la imagen de mirar por el espejo retrovisor de su automóvil mientras se alejaba del punto de partida y de su entorno más cercano. Con semejante sentido, los pentecostales suelen comentar, Biblia in mente, que al bautizarse abandonan las viejas vestiduras para ponerse ropas nuevas y limpias. Por descontado, la interiorización de las pautas ideológico-simbólicas relacionadas con el cuerpo afecta igualmente a los casos de adscripción religiosa, es decir, derivados de la incorporación original o generacional.

La comparación que pretendo llevar a cabo atiende sobre todo a las semejanzas, si bien en el ámbito de las posibles diferencias me referiré (den-

\footnotetext{
${ }^{1}$ Como mero criterio de estilo opto en adelante por utilizar solamente la voz masculina.
} 
tro del último apartado del texto) al culto a las imágenes. Es evidente, al mismo tiempo, que a priori los sistemas en cuestión son muy lejanos entre sí, en cuanto a las tradiciones religiosas a las que pertenecen y también a su ubicación concreta dentro del amplio mapa religioso contemporáneo. Sin embargo, en lo relativo a la experiencia corporal de los sujetos, que es la que aquí me interesa en particular, parecen existir diversas líneas de aproximación y otros tantos ámbitos convergentes. Líneas y ámbitos que, a su vez, dan pie a examinar otras confluencias de creencia, simbólicas y rituales de mayor calado. A través del cuerpo o del análisis de la dimensión corporal, pues, podemos llegar a ver cómo ambos sistemas son menos distantes de lo que objetivamente pueda parecer.

El movimiento Hare Krisna, más formalmente conocido como International Society for Krishna Consciousness (ISKCON), fue fundado en 1966 en Nueva York por Abhay Charan Bhaktivedanta Swami Prabhupada (18861977), un viejo guru procedente de la India y perteneciente a la antigua tradición gaudiya vaisnava. Swami Prabhupada — como era conocido familiarmente por sus primeros seguidores - difundió el mensaje de la Conciencia de Krisna entre los jóvenes y hippies de la contracultura, muchos de los cuales se convirtieron pronto en sus discípulos. La tradición gaudiya vaisnava arraiga históricamente en la Bengala de los siglos XIV y XV con la figura principal de Caitanya (1485-1533). Su motivo central es la adoración y la devoción absolutas a Radha-Krisna como realidad suprema, única y personal, a través de la práctica del bhakti-yoga (el yoga de la devoción), tal como es exaltado en textos sagrados de gran valor filosófico como el Bhagavad-Gita o los Puranas (en especial el Bhagavata Purana/Srimad Bhagavatam), y mediante el canto de los "Santos nombres" de Dios (Hare, Krisna y Rama), en tanto método considerado el más genuino y elevado para alcanzar la autorrealización.

Bhaktivedanta Swami, siguiendo la tradición de Caitanya, instauró el canto diario personal y repetido del maha-mantra (gran mantra) Hare Krisna (Hare Krisna, Hare Krisna, Krisna Krisna, Hare Hare, Hare Rama, Hare Rama, Rama Rama, Hare Hare) ${ }^{2}$, así como la exigencia de acatar cuatro principios regulativos básicos por votos de iniciación: adoptar una alimentación estrictamente vegetariana, no practicar sexo ilícito, es decir, fuera del matrimonio y sin finalidad procreadora, no participar en juegos de azar, generadores de deseos egoístas y materialistas, y no consumir ningún tipo de drogas ni productos considerados tóxicos, entre los que se incluyen el café, el té y

\footnotetext{
${ }^{2}$ Después de dos rebajas sucesivas, finalmente 1728 veces al día. Resultan ser dieciséis vueltas al rosario (japa) de 108 cuentas que los Hare Krisna reciben al ser iniciados.
} 
el tabaco. Otro principio fundamental en la teología de la Conciencia de Krisna es, de forma significativa: "uno no es este cuerpo, sino un alma espiritual al servicio eterno de Dios". Krisna debe ser, en efecto, el foco de toda atención y devoción. Junto a ello, para un correcto avance espiritual también es necesario aceptar a un maestro espiritual genuino y rendirle el oportuno respeto y servicio. La conversión religiosa, por último, toma el sentido de renacimiento antes mencionado, y se ajusta a un modelo revivalista, causal y evolutivo (Cf. Vallverdú 1999; 2001) que implica un cambio sustancial de la conciencia, la identidad y la conducta personales.

Por otra parte, por lo que se refiere al movimiento evangélico-pentecostal, se aceptan dos grandes variantes dentro de la gran tradición protestante: Por un lado, el protestantismo histórico, conformado por las denominaciones cercanas a la Reforma protestante del siglo XVI y caracterizadas por la formalización y la institucionalización, de cultura escrita y ligada a la intelectualidad de elite y con proyectos misioneros que suelen partir de las iglesias madres en los Estados Unidos. Por otro lado, el protestantismo pentecostal, surgido del evangelismo conversionista de la tradición metodista norteamericana del siglo XIX, con la figura prominente de John Wesley. El Pentecostalismo arraiga y se desarrolla mucho más en los ámbitos locales y populares. Destaca por sus acentos carismáticos, intensos, emocionales y participativos. Su base doctrinal es la llamada "Santidad del corazón", el cual debe quedar libre de todo pecado gracias a la intercesión del Espíritu Santo.

Desde 1895 algunos pastores evangélicos empezaron a predicar un bautismo de fuego y a principios del siglo XX, en Kansas y Los Ángeles, los movimientos de Santidad más radicalizados, derivados y escindidos del metodismo ortodoxo, comenzaron a poner de manifiesto emisiones glosolálicas entre los fieles ${ }^{3}$, que luego serían legitimadas por predicadores estudiosos de la Biblia como auténticas expresiones espirituales, pruebas definitivas y suficientes para esperar un nuevo descenso del Espíritu Santo que traería el Bautismo del Espíritu ${ }^{4}$. A partir de ese momento, y hasta la actua-

${ }^{3}$ La glosolalia, o fenómeno espiritual de hablar en lenguas desconocidas, es uno de los dones de mayor entidad que los creyentes pueden recibir por parte del Espíritu Santo y suele constituir, además, el sello de legitimidad para el bautismo. Cuando es así los hermanos pentecostales saben que una correcta exteriorización glosolálica (es decir, acorde con los parámetros carismático-institucionales) forma parte del consenso simbólico ritual y es la base para su incorporación en el seno de la comunidad religiosa. Algunos estudios específicos sobre la glosolalia son los de May (1956), Jaquith (1967), Goodman (1972), Hutch (1980) y Garma (1998).

${ }^{4}$ En su trabajo ya clásico sobre las sectas religiosas, Bryan Wilson lo resume como sigue para concretar la aparición del Pentecostalismo: "El movimiento de santidad había incitado a algunos predicadores a estudiar lo que las escrituras decían del bautismo del 
lidad, la insistencia en los dones y signos carismáticos de dicho bautismo sagrado ha venido constituyendo la marca distintiva del Pentecostalismo, junto con la utopía milenaria del segundo retorno de Cristo, el juicio y el Reino eterno.

El Pentecostalismo clásico surge, en definitiva, como una "religión del corazón" (Wilson 1970: 66), lo cual incluye efectos intensos de la experiencia religiosa sobre los fieles, con Dios como responsable de los mismos. Una religión acorde — también en este caso- con el perfil emotivo-afectivo, transformador y renovador de la conversión, que implica la salvación por la gracia de Dios mediante la fe en Jesucristo. Otros rasgos básicos del movimiento pentecostal tradicional en sentido amplio son la creencia en la Santa Trinidad (conformada por Dios, Jesucristo y el Espíritu Santo) ${ }^{5}$, la exaltación de la Biblia como fuente esencial de toda verdad, la fe en la efectiva y manifiesta potencia divina, la curación por la fe mediante la oración y la imposición de manos sobre el cuerpo, y la distribución de los dones o carismas del Espíritu entre los fieles ${ }^{6}$.

Espíritu, y los evangelistas, guiados tal vez por Charles F. Parham, del Bethel College, una escuela bíblica [...] fundada en Topeka (Kansas), llegaron a la conclusión, hacia 1900, de que el hablar lenguas era una prueba atestiguada por la Biblia de una experiencia del Espíritu. Algunos de estos estudiosos hablaban en lenguas, afirmando que el poder del Espíritu les hacía hablar en lenguas que jamás habían aprendido, pero que los otros reconocían como auténticas. Este fue el principio de un movimiento que pronto empezó a extenderse" (Wilson 1970: 70). Dos pasajes bíblicos pueden servir de complemento: "Está escrito en la Ley: En lenguas extrañas y con labios extranjeros hablaré a este pueblo, y ni aun así me escucharán. De suerte que las lenguas son señal no para los creyentes sino para los incrédulos, mientras que la profecía no es para los infieles, sino para los creyentes" (I Cor. 14, 21. 22). "Y sucederá en los últimos días, dice Dios, que derramaré mi Espíritu sobre toda carne, y profetizarán vuestros hijos y vuestras hijas, y vuestros jóvenes verán visiones, y vuestros ancianos soñarán sueños. Y sobre mis siervos y sobre mis siervas derramaré mi Espíritu en aquellos días, y profetizarán" (Hechos de los Apóstoles, 2. 17) (Nácar y Colunga 1973: 1450, 1378).

${ }_{5}^{5}$ Para los pentecostales éstas son las tres únicas divinidades reconocidas. El desdoblamiento de Dios en tres personas constituye la Santa Trinidad.

${ }^{6}$ Cabe distinguir este Pentecostalismo tradicional del llamado neopentecostalismo, surgido después de la Segunda Guerra Mundial y que tiene unas características algo diferentes. Con este concepto se suele designar a aquellos carismáticos surgidos de la tradición eclesial pentecostal que, en primer lugar, no parten del postulado de que la glosolalia es una evidencia necesaria del bautismo del Espíritu Santo. El sistema neopentecostal, por otra parte, cree en la restauración de la iglesia antes de la venida del Señor, el apostolado, también en la sanidad divina... y se vincula ya no tanto a las clases pobres y marginales, como ha venido siendo habitual en el Pentecostalismo clásico, sino mucho más a los sectores medios-altos urbanos. Además, tiene como singular y destacada estrategia expansiva el uso de la tecnología y los medios de comunicación de masas. 
Dentro de estas mínimas bases introductorias y de contextualización, cabe otro aspecto comparativo general junto a las simetrías de conversión ya citadas. En las ceremonias de ambos sistemas religiosos predomina muy claramente el aspecto sentimental, la fuerza del carisma y la expresión corporal por encima de todo. Son sistemas en los que el cuerpo se convierte, una vez más y de forma particularmente intensa, en el vehículo práctico, directo y efectivo de comunicación religiosa. Es el símbolo religioso por excelencia y el lugar donde se inscriben las utopías de salvación y liberación espirituales. También en los dos casos, a través del cuerpo y de las representaciones corporales se manifiestan las marcas de la identidad religiosa, de modo que los creyentes se convierten en auténticos "sujetos hablantes mediante el cuerpo" (Lacan 1981). Un supuesto clave en este sentido es que hermanos pentecostales y devotos de Krisna nos revelan con su cuerpo, por encima de todo, los aspectos más materiales, racionales y objetivos de la acción social; la activación de un sentido práctico internalizado que comanda su intencionalidad y su compromiso religioso.

Dicho esto, la prioridad del análisis empírico recae de nuevo en la dimensión práctica, en el plano de las prácticas religiosas y de su aprendizaje; o si se prefiere, del aprendizaje individual (dentro del marco colectivo) de un rol socio-religioso que incluiría como requisito central el seguimiento sistemático, repetitivo e institucionalmente controlado y regulado de códigos y prácticas. Esto incluye, claro está, considerar el importante papel jugado por los modelos carismáticos y jerárquicos institucionales que invariablemente sirven de pauta y guía a tal objeto y que corean el sentido, la razón de ser y la legitimidad de la praxis ritualizada dentro de ambos sistemas.

En el trasfondo teórico destacan los trabajos de Pierre Bourdieu, Génesis y estructura del campo religioso ${ }^{7}$ y El sentido práctico, y los de Bryan S. Turner, El cuerpo y la sociedad. Exploraciones en teoría social (1989), La religión y la teoría social. Una perspectiva materialista (1997) y Regulating bodies. Essays in Medical Sociology (1994). Junto a ellos, el famoso texto de Marcel Mauss, Técnicas y movimientos corporales (1991) y el mucho más reciente de Nancy Scheper-Hughes y Margaret Lock, The Mindful Body: A Prolegomenon to Future Work in Medical Anthropology (1987). Igualmente a tono con la perspectiva adoptada, resaltan algunos clásicos de la antropología religiosa y simbólica modernas. Me refiero a los influyentes análisis de Émile Durkheim sobre la efervescencia colectiva y el simbolismo ritual, de Marcel Mauss sobre intercambios y donaciones con significación sacra, de Mary Douglas sobre los conceptos de contaminación, pureza y peligro,

\footnotetext{
7 Traducido del original en francés (1971) por Alicia B. Gutiérrez, dentro de Bourdieu (2009).
} 
de James Fernandez sobre los procesos de consenso simbólico-religiosos y de Victor Turner respecto, entre otras cuestiones, a los modelos organizativos de estructura y communitas.

Me serviré muy puntualmente de ciertos resortes de este trasfondo teorético y conceptual general, o de otros afines al mismo, así como de algunas consideraciones planteadas con antelación, para desarrollar, a partir de ahí, la correspondiente reflexión comparativa en los diferentes niveles. Primero, no obstante, quiero sintetizar tres pilares centrales de interpretación: En primer lugar, la consideración de la religión como una de las instituciones históricas esenciales de control social de las relaciones sociales, en su mayor parte a través de la apropiación ideológica y simbólica del cuerpo y de lo corporal. En segundo lugar, y en conexión con esto, la comprensión del cuerpo como una de las formas fundamentales y sostenidas de control social en la sociedad contemporánea. Un cuerpo que sigue constituyendo -en la línea emprendida por Foucault - objeto del poder y del saber (Turner 1989). Los ejemplos ordinarios de ello pueden ser múltiples y diversificados, sobre todo en lo referente a construcción social y condicionamiento de los sujetos en el ámbito de su presentación e interacción pública. Por último, la compenetración teórica de fondo con el llamado "estructuralismo-constructivismo" o "estructuralismo genético" de Pierre Bourdieu ${ }^{8}$ que busca integrar o compatibilizar los paradigmas materialista-objetivista y fenomenológico-subjetivista a partir de una dialéctica dinámica y de aportación mutua entre los modelos clásicos de la estructura y del sujeto:

Se trata de escapar al realismo de la estructura [...] sin recaer no obstante en el subjetivismo, totalmente incapaz de dar cuenta de la necesidad del mundo social: por ello, es necesario retornar a la práctica, ámbito de la dialéctica del opus operatum y del modus operandi, de los productos objetivados y de los productos incorporados de la práctica histórica, de las estructuras y de los habitus (Bourdieu 2008: 86).

\footnotetext{
${ }^{8}$ Con esta conceptualización Bourdieu quiere indicar que no sólo importa la estructura sino también la génesis. Y que es en la génesis donde debe recuperarse la productividad de los agentes (Martínez 2009). Por un lado (en su versión estructuralista) existen en el mundo social estructuras objetivas, independientes de la conciencia y voluntad de los agentes, capaces de orientar o coaccionar sus prácticas o sus representaciones; y al mismo tiempo (en su versión constructivista), una génesis social de una parte de los esquemas de percepción, pensamiento y acción constitutivos de lo que llama habitus, y por otra parte estructuras, en particular de los llamados campos o grupos (clases sociales). De este modo, "el análisis de las estructuras objetivas es inseparable del análisis de la génesis en el seno de los individuos biológicos de las estructuras mentales que son por una parte el producto de la incorporación de las estructuras sociales y del análisis de la génesis de estas estructuras sociales mismas" (Bourdieu 1996: 26).
} 
Eduardo Menéndez (2000) hace una síntesis introductoria de ambas concepciones previamente a su mayor desarrollo analítico. Explica que la concepción que pone el eje en la estructura (estructura social, orden simbólico, "vida social») sostiene que ésta es la determinante de la subjetividad: la que crea, construye, impulsa, establece o determina el sistema de representaciones y de prácticas que manejan los sujetos. La estructura establece los márgenes dentro de los cuales el individuo piensa, escoge... limitando así su libertad, aunque eso no le impida elegir. Más allá de la intencionalidad o no de los actos de dicho sujeto, el sentido real de sus acciones está en la estructura, no en el propio comportamiento. Lo que el sujeto hace, finalmente, no es producir la estructura sino reproducirla. Por otra parte, las concepciones que basan su interpretación en el sujeto, proponen que el proceso de estructuración que implica la vida cotidiana consiste esencialmente en lo que los sujetos hacen, en su actividad y comportamiento. Éstos, al actuar, crean, modifican, recrean..., estructuran la realidad en el desarrollo mismo de sus prácticas. En este caso el individuo es del todo intencional, responsable y libre, y lo decisivo de la "vida social" no está en la estructura (que no explicaría las características de las acciones), sino en las (re)presentaciones y prácticas que ejercen los sujetos.

Con el fin de superar las limitaciones de ambas concepciones y dar contenido a la complementariedad y las articulaciones entre sujeto y estructura, Pierre Bourdieu recurre por un lado a la construcción de las estructuras objetivas; es decir, a lo que él llama el espacio de posiciones. Un concepto que alude, tal como explica Loïc Waquant (1995), a la distribución de los recursos socialmente eficientes que definen las coerciones externas que limitan las interacciones y representaciones de los sujetos. Pero al mismo tiempo vuelve a introducir la experiencia inmediata de dichos sujetos o agentes (activos, creativos, inventivos) en la vida ordinaria con el objeto de explicar las llamadas disposiciones, a saber, las categorías de percepción y apreciación que estructuran desde adentro sus acciones y representaciones (tomas de posición). Bourdieu insistirá además en las capacidades genetratrices o generativas de tales disposiciones, entendidas como adquiridas y socialmente construidas. En la necesidad, en suma, de reintroducir la práctica del agente, su capacidad de invención, de improvisación, no como la del sujeto trascendental en la tradición idealista, sino como la propiamente de un "agente actuante".

Así pues, aunque los dos momentos de análisis citados sean necesarios, no por ello tienen la misma importancia para el prestigioso sociólogo, quien, a propósito de la precitada "incapacidad subjetivista", señaló ciertos límites de la construcción fenomenológica - aun mostrando predilección a parte, dentro de la variante existencialista, por la figura de Merleau-Ponty y su 
influyente Fenomenología de la percepción (Cf. Bourdieu 1996). Para él, la fenomenología, "en su esfuerzo para someterse a la verdad vivida de la experiencia religiosa como experiencia personal, irreductible a sus funciones externas, omite operar la última 'reducción', la de las condiciones sociales que deben ser cumplidas para que esta experiencia vivida sea posible" (Bourdieu 2009: 63). De acuerdo a esta interpretación, Bourdieu acaba dando prioridad epistemológica a la ruptura objetivista en relación con la comprensión subjetivista:

La aplicación del primer principio durkheimiano del 'método sociológico', a saber, el rechazo sistemático de las prenociones, debe anteceder al análisis de la aprehensión práctica del mundo desde el punto de vista subjetivo. Esto, porque el enfoque de los agentes también varía de manera sistemática en función del sitio que ocupan en el espacio social objetivo (Wacquant 1995: 20).

De este modo, lo más importante (en la línea estructuralista) es el juego de relaciones objetivas entre posiciones. Antes que las interacciones entre individuos prevalece la definición de los agentes por sus posiciones. Agentes cuya acción, sumamente variable y adaptativa a las diferentes situaciones, no puede reducirse a la mera obediencia mecánica a las reglas ni tiene a la razón por principio (aunque obediencias y racionalizaciones existan claramente). Este planteamiento tiene que ver con las mismas nociones de habitus, en tanto productor de estrategias ajustadas objetivamente a cada circunstancia, y de sentido práctico, en la medida en que:

a) Las conductas pueden ser orientadas en relación a fines sin estar conscientemente dirigidas hacia esos fines. La noción de habitus fue inventada, si puedo decirlo, para dar cuenta de esta paradoja. Asimismo, el hecho de que las prácticas rituales sean el producto de un "sentido práctico", y no de una especie de cálculo inconsciente o de la obediencia a una regla, explica que los ritos sean coherentes, pero con esa coherencia parcial, nunca total, que es la de las construcciones prácticas (Bourdieu 1996: 22).

b) El sentido práctico, necesidad social vuelta naturaleza, convertida en esquemas motrices y automatismos corporales, es lo que hace que las prácticas, en y por aquello que permanece en ellas oscuro a los ojos de quienes las producen y en lo que se revelan los principios transubjetivos de su producción, sean sensatas, vale decir, habitadas por un sentido común (Bourdieu 2008: 111).

Sobre estas bases, asumo aquí la prioridad objetivista sin renunciar por ello a la riqueza analítica del íntimo juego activo, interactivo e interpretativo personal de los agentes religiosos. Y lo hago para defender un enfoque corporal que, por un lado, da prioridad a cómo se organiza y reproduce el control en un campo de poder concreto, el religioso, y que plantea globalmente, por otro lado, que dentro de ese enfoque, el núcleo de aná- 
lisis de la religión desde una óptica materialista debe ser la explicación de los orígenes, las funciones y los efectos de las instituciones y prácticas religiosas. Es decir, debe ser un análisis exhaustivo de las estructuras institucionales (generadoras y estructurantes), como instancias eficaces de objetivación de la realidad, de poder y de control, así como de los sujetos (y su subjetividad) en ellas inmersos cotidianamente, con las acciones prácticas que exteriorizan dentro de dicha estructura (de forma activa, creativa y adaptativa), para generarla, regenerarla, dinamizarla y reproducirla.

\section{BASES MATERIALES DE PRÁCTICAS Y CREENCIAS}

Hasta el momento he tratado las prácticas religiosas, y las técnicas a ellas asociadas, a partir sobre todo de los procesos normativos y de control que determinan la acción corporal de los sujetos y, a un nivel más amplio, van modulando su identidad ${ }^{9}$. Ahora, en este paso adelante, sugiero que junto a estas bases materiales de las prácticas se pueden identificar ciertas bases materiales de las creencias y visiones religiosas sobre el cuerpo. Retomo de Althusser (1998) argumentos teóricos ajustados a esta cuestión. Desde un enfoque postestructural, este autor planteó dos tesis para el análisis de la ideología. En primer lugar, la tesis según la cual la ideología representa las relaciones imaginarias de los individuos con sus condiciones reales de existencia. Y en segundo lugar la que sugiere que la ideología tiene de forma explícita una existencia material. Para él, las "ideas" o "representaciones" que se ven como conformadoras de la ideología no tienen una existencia ideal

\footnotetext{
${ }^{9}$ Considero esos procesos de control ligados a la estructura organizativa y fundamentadora de los órdenes simbólico y social de los sistemas religiosos en cuestión. A las dimensiones propiamente organizativas, socializadoras y disciplinarias de la misma. O si se quiere decir de otra manera: al conjunto de condiciones objetivas que estructuran, disponen y regulan la vida colectiva y la conducta y actividad creadora de los sujetos. Tal como en ambos sistemas está constituida, dicha estructura tiene un perfil institucionalizado y objetivante de papeles, posiciones, relaciones y racionalizaciones bien definidas y pautadas, comprensibles y fundamentales para quienes las comparten y listas, además, en toda su objetividad, para ser reproducidas a partir de un trabajo religioso reiterado de producción e inculcación de creencias y habitus. Existe, en efecto, todo un cuerpo normativo y de saberes explícitos, explícita y deliberadamente sistematizados, destinado a reproducir el capital religioso a través de una acción pedagógica expresa y estratégicamente dispuesta. La estructura (estructural) así entendida, contiene en ambos sistemas el espacio de posiciones en los términos precitados de Pierre Bourdieu. Y los sujetos o agentes activos, aunque productores de sus propias visiones e ideas, están supeditados a ciertas disposiciones, las cuales organizan y estructuran desde adentro sus posicionamientos, representaciones y acciones.
} 
[idéale o idéelle] o espiritual, sino una existencia material. Una ideología, además, que siempre se materializa institucionalmente (los aparatos del Estado son la referencia singular de Althusser) y se plasma en forma de una práctica o una serie de prácticas:

Ideology existing in a material ideological apparatus, prescribing material practices governed by a material ritual, which practices exist in the material actions of a subject acting in all consciousness according to his belief (Althuser 1889: 160).

Para centrar algo más este ámbito, e inspirándome además en Victor Turner (1988), distinguiré entre bases materiales tipo estructura y bases tipo anti-estructura. Las primeras se relacionarían con el contenido jerárquico intradoctrinal, y en particular, por ejemplo, con el paralelismo organicista que se establece cuando se definen los diferentes estamentos y grados espirituales constitutivos del cuerpo religioso considerado único. Así lo vemos claramente en algunos pasajes bíblicos:

Porque el cuerpo no es un solo miembro, sino muchos / Los miembros son muchos pero uno solo el cuerpo / Pues vosotros sois el cuerpo de Cristo y (sus) miembros parciales / Y Dios los estableció en la Iglesia, primero apóstoles, luego profetas, luego doctores, luego el poder de los milagros, las virtudes; después las gracias de curación, de asistencia, de gobierno, los géneros de lenguas (I Cor. 12.14, 20, 27, 28) (Nácar y Colunga 1973: 1448).

También el Srimad Bhagavatam (Canto cuarto. Parte primera, 14. 45) refleja la ideología como relación imaginaria para las relaciones reales, al apelar a los diferentes órdenes socio-espirituales védicos, incluyendo además distinciones según el color de la piel ${ }^{10}$ :

En los sastras se dice que, en el cuerpo, la cabeza representa a los brahmanas, los brazos a los ksatryas, el abdomen a los vaisyas y las piernas, que comienzan con los muslos, a los sudras. De los sudras se dice a veces que son negros, krisna. De los brahmanas se dice que son sukla, blancos y los ksatryas y vaisyas son una mezcla de blanco y negro [...] En conclusión, se puede establecer que la piel de la casta superior es blanca o dorada, y que la piel de los sudras es de color negro (Bhaktivedanta Swami Prabhupada 1990: 542).

${ }^{10}$ Anticipo que todas las citas a los textos sagrados del movimiento Hare Krisna (en este artículo especialmente el Bhagavad-Gita y el Srimad Bhagavatam), se corresponden con la traducción e interpretación de los pasajes originales del sánscrito realizadas por el maestro fundador del movimiento A. C. Bhaktivedanta Swami Prabhupada. El Srimad Bhagavatam en particular consta de cinco "Cantos", integrados en diferentes volúmenes (siete en la edición lanzada por The Bhaktivedanta Book Trust). En todos ellos aparecen referencias a los temas asociados a la corporalidad que aquí selectivamente se tratan. 
La tradicional organización social por castas, prolongación de este esquema del brahmanismo en el marco del hinduismo, revelaría claramente la fuerte plasmación material del sistema cultural y de las creencias. Y en definitiva, en ambos casos, el modelo corporal sería la base para construir una ideología que, a su vez, legitima otro elemento material, la desigualdad social ${ }^{11}$. También en las dos tradiciones la plasmación de dichas creencias en movimientos religiosos concretos conlleva la fijación de los correspondientes órdenes jerárquicos y cargos internos que operan en el nivel práctico dentro del cuerpo religioso ${ }^{12}$.

Por otro lado, las bases materiales anti-estructura tendrían que ver con la diferenciación, la oposición y las alternativas existenciales y de práctica espiritual que dichos sistemas han manifestado frente al ensamblaje institucional-religioso dominante u oficial. Si nos remitimos a sus matrices

${ }^{11}$ Dentro del análisis político de la religión realizado por Pierre Bourdieu (es decir, observándola a la luz de los procesos de poder y dominación social) una idea importante es precisamente que "la intervención más poderosa de los clérigos no reside en el apoyo a tal o cual grupo político en un momento dado [clamorosas evidencias de esto aparte] sino en el efecto de imposición de la jerarquía misma, de un modo jerárquico de pensamiento que ordena el cielo tal como está ordenada la tierra, y así, naturaliza, sacralizándolo, el orden social existente" (Martínez 2009: 24; la apreciación entre corchetes es mía).

${ }^{12}$ La iglesia La Luz del Mundo puede ser un buen ejemplo en el caso evangélicopentecostal, con un cuerpo ministerial bien establecido y presidido en la cúspide por su líder carismático Samuel Joaquín. Dentro de este cuerpo se integran los pastores, también llamados "obispos", que pueden diferenciarse en doctores, profetas y evangelistas. Después están los diáconos, los encargados y por último los obreros. Las mujeres también siguen una jerarquía interna, encabezada por las diaconisas y con un papel también importante de las encargadas de las obras materiales (Cf. Vallverdú 2008: 110-111). En el movimiento Hare Krisna, por su parte, se distinguen cuatro grandes órdenes en relación a los miembros masculinos (las mujeres, o "madres", únicamente se categorizan como célibes o casadas): Brahmacarya, gribjasta, vanaprastha y sannyasa. Estos órdenes constituyen un ciclo completo de experiencia y crecimiento espirituales. La primera etapa (brabmacarya) es de celibato, formación espiritual y entrega absoluta al servicio devocional. La posible opción de abandonar el celibato implica convertirse en gribjasta, etapa en la que el devoto casado debe asumir las responsabilidades de la vida familiar y trabajar para el desarrollo del movimiento. Las dos últimas etapas implican retomar, de un modo profundo y lo más exclusivo posible, el camino de dedicación espiritual y devoción a Krisna. En la etapa vanaprastha el devoto inicia una vida retirada y contemplativa orientada a desvincularse progresivamente de los lazos terrenales y a prepararse para la renuncia definitiva al mundo, formalizada finalmente con la orden de sannyasa, que es la más elevada y suele corresponderse con la figura de los swamis y gurús, maestros espirituales que están en la cima organizativa y espiritual del movimiento y bajo los cuales se despliega la jerarquía interna de los diferentes templos a nivel nacional e internacional. 
históricas y doctrinales, los dos sistemas de creencias tratados —como la mayoría de las nuevas emergencias religiosas a lo largo del tiempo- se confrontan a las estructuras de poder propias de la ortodoxia socio-religiosa dominante. $\mathrm{Y}$, acorde con lo que suele representar todo nacimiento de una nueva religión, lo hacen constituyéndose en minorías espirituales efervescentes e innovadoras de orientación contra-hegemónica en los dominios social, cultural y propiamente religioso. Lo veremos algo más adelante.

Ambos sistemas, por otra parte, sintonizan con lo popular, son especialmente receptivos a las situaciones marginales para reclutar nuevos miembros y proponen una relación lo más directa posible con la divinidad en el ámbito de la experiencia religiosa. Los intermediarios institucionales (predicadores, pastores, maestros espirituales, gurus) están presentes en el papel carismático que les corresponde, ejerciendo liderazgo y control; sin embargo, en términos de la espiritualidad más propia y genuina, la vivencia íntima de Dios es un rasgo esencial tanto de la Conciencia de Krisna como del Pentecostalismo.

Sabemos que en la historiografía religiosa las manifestaciones extáticas o de exaltación emocional han sido objeto de frecuente rechazo y estigmatización. Desde ciertas perspectivas, la fe se puede y se debe expresar, pero parecería que solo hasta cierto punto o con moderación. Dentro de la tradición cristiana en particular, se encuentran múltiples ejemplos de ello en movimientos carismáticos, revivalistas o proféticos de distinto tipo, en muchas sectas conversionistas o milenaristas, o bien, a un nivel más individualizado, en las figuras de místicos, monjes o ascetas de diferentes épocas y lugares. Un rasgo común de todos estos casos, además, es que han planteado un mensaje diferente u opuesto al oficial o a la ortodoxia, han pretendido innovar o renovar (a nivel personal y colectivo), y a menudo han acogido o atendido a sectores sociales desfavorecidos u oprimidos y tratado de recuperar las esencias de humanidad, compasión, fraternidad, amor, justicia... contenidas en la religión.

La historia nos ha venido demostrando, efectivamente, de una forma bastante recurrente, que frente a la hegemonía material y oficializada aparecen las innovaciones contra-hegemónicas de acento espiritual o místico; frente al anquilosamiento institucional de lo religioso, la reactivación de la comunidad intensa y dinámica; frente a un cuerpo sacerdotal aposentado, los líderes, profetas, maestros y predicadores apasionados, con carisma personal y destinados a avivar la conciencia, o a defender a los oprimidos; frente al formalismo y la sobriedad litúrgica los cultos participativos, extáticos, etc.

Los sistemas que nos ocupan y sus integrantes vivieron también en sus comienzos un rechazo de las instancias establecidas o hegemónicas. Un rechazo que, con pocas excepciones contextuales y coyunturales, se ha 
mantenido también en ambos casos a partir de la imagen desacreditadora de secta. Reteniendo esa imagen negativa laboriosamente construida desde otros ámbitos de manipulación de lo mental y simbólico, para muchos, los Hare Krisna siguen siendo una secta destructiva y para otros tantos algo parecido son los creyentes pentecostales. Ciertas iglesias evangélicas incluso evitan reconocerse como pentecostalistas, debido a la imagen asociada de secta. De hecho, dentro de la tradición cristiana la descalificación de ciertos tipos de piedad religiosa, consideradas escasamente "espirituales" por parte de la Iglesia católica no es nada nuevo:

[Más bien] se inscribe en el rechazo que, desde Erasmo, han explicitado los sectores más modernizadores de la Iglesia católica hacia las formas "no controladas" de religiosidad, sobre todo las que pudieran resultar demasiado extrovertidas y sensuales como para ser asimiladas al modelo de piedad intrínseca y privatizada que la Reforma impuso como la única legítima (Delgado 1998: 57) ${ }^{13}$.

En efecto, la cuestión de la legitimación es siempre central cuando tratamos con discriminaciones sociales y culturales de diferente tipo. Con expresiones del poder en definitiva. Y también es un aspecto clave, en el mismo sentido, dentro del ámbito histórico de la interacción y la competencia o rivalidad ideológico-religiosa. Veamos pues, a partir de aquí, los procesos de oposición a la estructura que se querían señalar en relación a las bases materiales de las creencias de ambas tradiciones religiosas.

En el siglo XVI la Reforma protestante supuso un fuerte ataque al poder de la Iglesia de Roma. No sólo le sustrajo vastas y populosas regiones bajo su control, sino que también repudió la necesaria mediación de la iglesia en las relaciones entre Dios y el hombre, sosteniendo que cada uno puede interpretar los libros sagrados con "plena libertad de conciencia". Supuso, pues, un triunfo del individualismo en el plano religioso y además un apoyo importante a la cultura popular porque combatió extensamente el analfabetismo, con el fin de que todos los fieles pudieran acercarse a la lectura de los textos sagrados que muchos de los grandes reformadores se habían ocupado de traducir a las lenguas nacionales.

La ruptura que marca la Reforma protestante vendrá seguida por otras rupturas en el seno de la misma tradición protestante que profundizarán aún más en la experiencia religiosa personal, íntima, no elitista y poco formalista. Entre ellas, la del Pentecostalismo en relación con el movimiento fundamentalista de las Asambleas de Dios. Un argumento central de los fundamentalistas para rechazar al movimiento pentecostal fue el bautismo del Espíritu Santo, unido al momento del éxtasis provocado por la glosolalia.

${ }^{13}$ La traducción del catalán es mía. 
En realidad, dentro del mismo movimiento pentecostal, dos problemas teológicos no resueltos, la santificación y la Trinidad, dieron lugar originalmente a corrientes internas diferenciadas ${ }^{14}$. En cualquier caso, la devoción y la experiencia íntima y directa (corporal) de la divinidad son elementos invariables y fundamentales.

En la India, la doctrina del místico Caitanya, revitalizador del movimiento krisna-bhakti en la Bengala también del siglo XVI, rompió con la tiranía social del brahmanismo dominante y propuso una práctica religiosa orientada igualmente hacia el pueblo y que daba prioridad a la devoción más personal y a la expresión emocional y extática. En esa época los brabmanas (casta sacerdotal) dominaban el orden social y procuraban mantener la rigidez del sistema de castas y su liderazgo político. En este contexto, el vaisnavismo se convirtió en el movimiento más significativo de Bengala, y los vaisnavas, a pesar de su reducido número, se fueron organizando en pequeños grupos y siguieron las lecturas del Bhagavata-Purana, que propugnará un nuevo modelo social y una religión plenamente devocional.

El movimiento krisna-bhakti encabezado por Caitanya fue un movimiento entusiasta que, según Dimock (1996a), tenía tres características que en nada se asociaban al estatus dominante: a) Se expresaba a través del lenguaje vulgar, no en sánscrito, b) Rechazaba el rol del brabmana o sacerdote como intermediario entre Dios y los hombres, e incluso con frecuencia iba va más allá oponiéndose completamente al sistema de castas y c) Proponía una religión emocional, con el canto y el baile como parte de la búsqueda de una comunión extática e inmediata con la divinidad. Todos estos rasgos, a los cuales habría que añadir el hecho de reclutar sobre todo miembros de las clases más desfavorecidas o marginales, lo distinguían de otros movimientos coetáneos, especialmente en lo relativo a mensaje espiritual y doctrina social. El Bhagavata-Purana en particular, como fuente privilegiada, no representa en absoluto el punto de vista de la ortodoxia social y económica vigente. Más bien ricos y poderosos, eruditos y partidarios influyentes del statu $q u o$, aparecen como los principales oponentes de la religión devocional tal como es presentada en el Bhagavata: como un elogio a la pobreza y a la compasión por el angustiado o desfavorecido socialmente (Hopkins 1966).

\footnotetext{
${ }^{14}$ De hecho, la discusión seguía latente en las iglesias pentecostales mexicanas donde realicé trabajo de campo en 1999: La iglesia La Luz del Mundo antes mencionada, la iglesia de Dios Cristiano Apostólica Pentecostés-Even Ezer y la Iglesia del Dios Vivo Columna y Apoyo de la Verdad. Mis informantes clave me expresaron criterios y visiones diferentes respecto a la Santa Trinidad, y matizaban también de distinta manera el valor y el peso específico de Jesucristo en su interior, compartiendo sin embargo el principio básico de que su papel es esencial para la salvación humana.
} 


\section{HABITUS RELIGIOSO E IN-CORPORACIÓN}

Enfocaré ahora hacia el concepto de habitus. Un habitus que, según Pierre Bourdieu (2008), rige la acción personal, producto de la internalización de muchas estructuras externas y que es responsable de las operaciones prácticas que los sujetos ponen en marcha para alcanzar ciertas metas, ceñidos, con ese propósito, a un conjunto bien estructurado de reglas y a su obediencia —en la línea vertebradora del modelo de Bryan Turner (1994). Operaciones prácticas, por otra parte, orquestadas colectivamente y a la vez producto de una acción organizadora concreta.

Las estructuras organizativas de los movimientos religiosos aquí analizados funcionan en ese sentido, apelando a una disposición normativa legitimada por la tradición y las escrituras sagradas de referencia ${ }^{15}$, y al mismo tiempo a un modelo de comportamiento reconocido y pautado colectivamente que debe ser asumido por los sujetos. Las reglas son in-corporadas, se manifiestan a través de los cuerpos. Y luego son esos mismos cuerpos regulados los que exigen y controlan el cumplimiento de las reglas, respecto a uno mismo y observando a los demás. Los cuerpos son el soporte físico y experiencial del control normativo y social. Son, en definitiva, cuerpos políticos (Scheper-Hugues y Lock 1987).

En realidad, la misma memoria del cuerpo y sobre el cuerpo es una memoria del cuerpo político. Las ataduras y los sufrimientos relacionados con el cuerpo en el mundo material y mundano tienen representación recurrente en las historias de conversión dentro de ambos sistemas. Son experiencias que se reinventan con el fin de invertirse ideológica y ritualmente con la nueva vida espiritual adoptada. Pero a la vez tienen una base material, aunque el cuerpo en el presente sea dominado de otra manera: ahí tenemos, por ejemplo, el celibato propio del estado brabmacarya en la Conciencia de Krisna y la similar vida austera, casta y sexualmente contenida que se exige a los feligreses pentecostales.

Sin embargo, esta nueva situación religiosa no suele vivirse como una dominación o inhibición corporal de connotación opresiva o asfixiante. Por el contrario, las contenciones y las rutinas regladas son naturalmente aceptadas por hermanos y devotos como medio para dar un giro a su vida. Forman parte, en efecto, de su habitus religioso, están inscritas en él y dispuestas para él. Aunque en el marco de los parámetros comunes, el «senti-

15 Obviamente, la Biblia en el caso evangélico-pentecostal en general, y sobre todo, como ya he señalado, el Bhagavad-Gita y el Bhagavata-Purana o Srimad-Bhagavatam en el caso del movimiento Hare Krisna. 
do del juego" (volviendo a Bourdieu) siga operando y variando de acuerdo a las circunstancias, comprensiones y racionalizaciones personales. El modelo institucional imprime un habitus, incluso para la propia narración biográfica de los agentes, pero a la vez los agentes pueden expresar o generar vivencias e interpretaciones diferentes sobre los símbolos religiosos y sobre ese mismo modelo que asumen.

En cualquier caso, otra vez nos encontramos con bases materiales de las prácticas y bases materiales de las creencias: tales creencias proponen que el sujeto debe reformarse y transformarse, y así lo aceptan hermanos y devotos mediante la acción práctica-corporal disciplinada. Una reforma y transformación que, por lo demás y en el mejor de los casos, debe visibilizarse en el mismo cuerpo en términos de salud física y mental, de sentimiento de felicidad al fin y al cabo. Krisna es considerado "la fuente de toda felicidad", y recibir al Espíritu Santo es lo máximo a nivel emotivo y placentero. El cambio de apariencia también es requisito, lo cual influye, claro está, en la manera de vestirse y de decorar el cuerpo: en el caso Hare Krisna, el dhoti y la kurta (prendas superior e inferior), la sikha (coleta), la señal vaisnava marcada en la frente... Todo ello indica el correcto porte de los devotos, para su presentación personal y pública; las devotas, por su parte, y en el mismo sentido, deben llevar el sari hindú ocultando su cuerpo hasta los pies y la cabeza cubierta, manteniendo una actitud recatada y sensualmente discreta, sobre todo para no perturbar la mente masculina.

De forma simétrica, particularmente dentro de los escenarios religiosos, las mujeres pentecostales llevan también su mantellina en la cabeza, largos vestidos que cubren completamente su cuerpo, no usan maquillaje, no curvan ni rizan su cabello y dejan de usar o comprar prendas de corte sensual, sugerentes o llamativas. Esto es debido, además del mismo respeto a la sensibilidad de los hombres, a una lectura selectiva de los mandatos bíblicos que valoran el cabello extenso, no cortado, que a la mujer "le ha sido dado por velo" (I Cor. 11, 13-15), o que prohíben el uso de vestimentas masculinas por parte de las mujeres, por ejemplo los pantalones (Dt. 22, 5). En todo momento el énfasis recae en la apariencia natural propia, sin artificios externos, de modo que cada persona se crea hermosa por lo que es y por como es, creada por Dios.

La alta significación de la sexualidad resalta igualmente en ambos casos. Las categorías de puro e impuro suelen ser movilizadas para controlar o domesticar la conducta de ambos géneros. El cuerpo, y en particular su reproducción y su vinculación al placer, han sido siempre objeto de un control ambivalente por parte de la religión. En este sentido, la conducta sexual se ha simbolizado y manejado de forma diferente de acuerdo a las diferencias de sexo, edad y estatus social y religioso (Campiche 1996). El 
cuerpo asume, así, un doble significado y simbolismo: es a la vez lugar de realización espiritual y un obstáculo para alcanzarla:

En los sistemas religiosos, el cuerpo es un vehículo para la transmisión de la santidad y un importante símbolo del mal como "carne"; es el medio por el cual se educa nuestra alma, y a la vez el obstáculo para nuestra salvación (Turner 1997: 12).

La construcción de la identidad, por lo tanto, pasa primero por una construcción simbólica del cuerpo asociada, tanto a la experiencia vivida, como, por encima de ésta, a la disciplina colectiva exigida, organizativa y reguladamente. Patrones de conducta objetivada a nivel institucional sirven para canalizar la subjetividad más intensa en ambos casos. Resurge de este modo la estructura de poder aplicado al cuerpo y la estructura que confiere poder al mismo cuerpo: el poder sobre el cuerpo religioso y el poder del cuerpo religioso, como reza el título de este artículo. Poder sobre el/ del cuerpo para, en el caso del Pentecostalismo, por ejemplo, dar entrada al Espíritu Santo (en el mejor de los casos) o dar salida al demonio (en el peor) si es necesario; gracias, en esta segunda situación más crítica, a las operaciones prácticas realizadas por el pastor carismático con poderes divinamente conferidos de sanación y basados en la eficacia simbólica. Poder sobre el/del cuerpo para, en semejante contexto, manifestar la fuerza de la fe y así obtener una curación milagrosa, o bien para remarcar la potencia de la comunidad religiosa de pertenencia como locus colectivo sacralizado. Los Hare Krisna saben igualmente (lo dice la autoridad de la estructura) de ese poder corporal para superar los egoísmos materiales (producto del ego falso) y los placeres carnales, sensuales y sensoriales del mundo focalizándolos y sublimándolos en la devoción personalista a Krisna, las demás deidades de su panteón y su maestro fundador.

En ambos sistemas, los aspectos mundano-materiales que los sujetos tratan de superar — con la cuestión sexual de forma destacada- se corresponden, en realidad, con aquello que la religión puntualiza e incluso maximiza en sus principios. Así, por ejemplo, sabemos que la doctrina del pecado (original y ordinario, por pensamientos y por obras, etc.) es un puntal de la tradición cristiana, y los pentecostales la recuperan con el máximo fervor. Por otra parte, los contenidos místico-eróticos de la Conciencia de Krisna están ya presentes en los antiguos cultos vaisnavas, en especial los sahajiya (ver Dimock 1966b), así como también en las escrituras sagradas más relevantes del bhagavatismo. De hecho, las dimensiones mitológicas y rituales del culto devocional a Krisna implican toda una serie de dinámicas tan minuciosas como complejas en este sentido. Se ilustran bien las primeras a través de la encarnación terrenal de Krisna como persona divina, mostrando, del lado más "humano", sus "pasatiempos" amorosos con las 
pastoras (gopis) de vacas en Vrindavan (India) ${ }^{16}$. Esas dinámicas también aparecen en el ámbito de los cultos religiosos de este movimiento, con el detallista e íntimo trato a las divinidades o la presentación individual y/o colectiva del cuerpo en diferentes ambientes, privados o públicos, y en situación cotidiana o explícitamente mística.

En el sistema de la Conciencia de Krisna nos encontramos con cuatro pilares fundamentales de la vida piadosa: la misericordia, la austeridad, la limpieza y la veracidad. Cada uno de ellos se corresponde con los cuatro pilares sobre los que se mantiene la vida pecaminosa, siempre vinculados a la experiencia y la acción corporal y en gran medida responsables de que la firmeza estructural perdure a partir de su negación: el comer carne (destruye la misericordia y la compasión), el sexo promiscuo, la intoxicación (consumen la austeridad) y el juego de azar (arruina la veracidad). En el sistema pentecostal, el pilar central es arrepentirse de los propios pecados (que lógicamente derivan de conductas mundanas inadecuadas) y aceptar a Jesucristo como salvador ${ }^{17}$. A partir de ahí se instaura la necesidad de ser bautizado por el Espíritu, con todo el compromiso personal que ello implica, y la insistencia en demostrar la fe con palabras y con obras. Es entonces cuando se estará en el camino correcto hacia la salvación y entre los elegidos para alcanzar la vida eterna.

Por otra parte, la sacralización del cuerpo dentro del dominio religioso empieza con uno mismo, tanto entre los Hare Krisna, como entre los pentecostales evangélicos; remite a la identidad personal (self): el cuerpo propio es considerado un "templo divino" (Vallverdú 2009a). Dios es uno, y el templo (corporal) que lo recibe o acoge también es único y personal. En este sentido, fenómenos tales como la eventual in-corporación del Espíritu Santo y la modificación de la conciencia (en el contexto de estados de trance y posesión) están presentes entre los pentecostales de una forma

${ }^{16}$ Otro texto sagrado, El libro de Krisna / Krisna. La Suprema Personalidad de Dios, es un exhaustivo compendio de la elaborada mitología y su simbolismo en torno al Krisna más "terrenal". En lo relativo en particular a su relación con las gopis, véanse especialmente pp. 150 a 243.

${ }^{17}$ Sirvan también algunos pasajes bíblicos de muestra: "Que ninguno, pues, os juzgue por la comida o la bebida, por las fiestas, los novilunios o los sábados. Sombra de lo futuro, cuya realidad es Cristo / 'No tomes, no gustes, no toques' / Todas estas cosas son corruptibles con el uso, conforme a los preceptos y enseñanzas de los hombres" (Col. 2. 16, 21, 22). "Pues sabemos que nuestro hombre viejo ha sido crucificado para que fuera destruido el cuerpo y ya no sirvamos al pecado / Así, pues, haced cuenta de que estáis muertos al pecado, pero vivos para Dios en Cristo Jesús / Que no reine, pues, el pecado en vuestro cuerpo mortal, obedeciendo a sus concupiscencias" (Rom. 6. 6, 11, 12) (Nácar y Colunga 1973: 1484, 1424). 
sobresaliente y fundamental ${ }^{18}$. De forma similar, el devoto de Krisna está completamente seguro de no ser el cuerpo físico, al que considera un simple envoltorio temporal del alma; almas espirituales es lo que realmente somos $^{19}$. Ser almas espirituales implica usar su cobertura efímera y fastidiosa, el cuerpo, solo para glorificar a Krisna y, además, refleja un tipo de transposición simbólica de lo societario hacia lo individual: la sociedad se asocia al "mundo material" y al cuerpo, o a un determinado modelo de cuerpo más concretamente, hedonista y puesto al servicio de la propia gratificación; el individuo, al alma, al dominio de lo espiritual donde uno debe buscar y tener su lugar y autocomprenderse como servidor eterno e incondicional de Dios.

\section{NATURALIZACIÓN, RUTINIZACIÓN Y PLAUSIBILIDAD}

En uno y otro sistema, la naturalización y rutinización sistemáticas de la acción social, corporal y normativa hacen difícil discutir lo inscrito en el sentido común desde el momento de la iniciación (Hare Krisna) o del bautizo (Pentecostalismo). Contravenir lo que pertenece desde ese momento al reino de los significados intersubjetivos y colectivamente compartidos; a las relaciones convenientes y a la jerarquía marcada. Cuestionar aquello que, tal como el converso sabe, va forjando la nueva identidad personal, social y religiosa del devoto de Krisna o del hermano pentecostal. Aquí no es solamente lo obvio lo que no necesita ser cuestionado. Lo obvio, además, descansa sobre un fundamento sagrado y omnicomprensivo, y en los niveles de la adhesión o adscripción personales, debe asegurar un compromiso sin ambigüedades ${ }^{20}$. Las crisis de fe —claro está que ni mucho menos ex-

${ }^{18}$ Volvemos a la Biblia: “¿No sabéis que sois templo de Dios y que el Espíritu de Dios habita en vosotros? Si alguno destruye el templo de Dios, Dios le aniquilará / Porque el templo de Dios es santo, y ese templo sois vosotros" (I Cor. 3. 16, 17).

${ }^{19}$ En el Srimad Bhagavatam (3. 22) se dice: "El vaisnava ve el cuerpo como un templo de Visnu. El señor Siva, siendo consciente de Krisna, ya había prestado los debidos respetos a la Superalma, y por lo tanto ya había ofrecido sus respetos a Daksa, el cual se identificaba con el cuerpo. No había ninguna necesidad de ofrecer respetos al cuerpo, pues ningún mandamiento védico lo ordena" (Bhaktivedanta Swami Prabhupada 1990: 88). Pero también la Biblia argumenta: “¿O no sabéis que vuestro cuerpo es templo del Espíritu Santo, que está en vosotros y habéis recibido de Dios, y que por lo tanto no os pertenecéis? / Habéis sido comprados a precio. Glorificad, pues, a Dios en vuestro cuerpo" (I Cor. 4. 19, 20) (Nácar y Colunga 1973: 1442).

${ }^{20}$ En este sentido, siguiendo a Bourdieu, la religión asume una clara función ideológica, pero a la vez política y práctica de "absolutización de lo relativo y legitimación de 
clusivas de los casos aquí tratados- son una muestra de que es preferible, subjetivamente hablando, que dicho fundamento no sea puesto en duda. No tanto por la problemática subjetiva que la inestabilidad emocional pueda acarrear (y que de hecho acarrea), sino más bien, en términos colectivos, por el fallo que anuncian en la resocialización y en la estructura de plausibilidad que la organización promueve. Cuando alguna crisis personal emerge, por leve que sea, los procesos de asunción, naturalización y rutinización se ven desafiados; y con ellos los más estructuradores mecanismos de motivación, compromiso y control institucionales.

Algo no funciona bien si el sujeto, una vez las acciones han sido asumidas, naturalizadas y rutinizadas, pierde el control de su propia actividad corporal. Perder ese control es sin duda negativo y contraproducente, tanto entre los Hare Krisna como entre los cristianos pentecostales, en términos organizativos-rituales y en términos más profundos de memoria e identidad. El adiestramiento y las técnicas corporales de Marcel Mauss (1991) exigen un rigor que no debe desmoronarse en los sistemas que aquí nos ocupan. Adoctrinamiento sistemático y aprendizaje de rol son factores de primer orden. De su validez depende en buena medida el equilibrio del sujeto y de la comunidad; y a partir de ahí de la estructura que rige y dirige sus experiencias, interacciones y representaciones. Sin sujetos fieles, operativos y practicantes, el ensamblaje racional y relacional que articula la organización de los movimientos pierde consistencia y debe activar estrategias alternativas para asegurar su producción y reproducción. Todo indica, en cambio, que si el proceso resocializador, moralizador y concienciador es lo bastante eficaz, resultarán de él cuerpos espirituales, cuerpos místicos, convencidos, con un cuadro de esperanzas y recompensas últimas por delante -cuadro, no obstante, invariablemente vinculado al mundo empírico y sus circunstancias.

El actor fenomenológico vuelve a ser en este ámbito el auténtico protagonista, si bien el factor colectivo-institucional persiste como determinante. La citada in-corporación del Espíritu Santo a través del trance es una vivencia, sin duda, extremadamente personal en el Pentecostalismo. Pero, por lo general (no de forma exclusiva), acontece dentro de un contexto de inducción colectiva bien pautado y suele ser validado por el pastor. Los estados inductores del cuerpo, en efecto, hacen surgir a su vez estados del alma. Y

lo arbitrario". Es un sistema simbólico estructurado y estructurador que tiene como punto clave de interés el tratar de construir y expresar la experiencia en calidad de "lógica en estado práctico" y de "problemática implícita", la que atañe al "sistema de cuestiones indiscutidas que delimitan el campo de lo que merece discusión por oposición a lo que está fuera de toda discusión, por lo tanto admitido sin discusión" (Bourdieu 2009: 60). 
se realizan en el contexto de ceremonias cuya intención explícita es lograr una eficacia simbólica legitimadora. Con el fin, en suma:

De ordenar los pensamientos y de sugerir los sentimientos a través del ordenamiento riguroso de las prácticas, la disposición regulada de los cuerpos y en particular de la expresión corporal de la afectividad, ya sean risas o lágrimas. El principio de la eficacia simbólica podría encontrarse en el poder que otorga sobre los otros, y especialmente sobre sus cuerpos y sus creencias, sobre los montajes verbo-motores más profundamente ocultos, ya sea para neutralizarlos, ya sea para reactivarlos haciéndolos funcionar miméticamente (Bourdieu 2008: 112).

Por su parte, el éxtasis momentáneo o creciente que supuestamente puede conseguirse con el proceso práctico y regulado (sadhana) del bhakti entre los Hare Krisna también debe ser contemplado en términos muy individuales y subjetivos, dependiendo, como entre los hermanos pentecostales, sobre todo del nivel de conciencia y del avance espiritual de cada devoto. Sin embargo, es la estructura y sus programas espirituales los que imponen rangos, tiempos y espacios pertinentes para la explosión emocional, y la jerarquía la que acaba definiendo los estados de avance espiritual de cada sujeto (según el nivel en que son colocados, ellos a menudo racionalizan y expresan el grado místico-emocional que les corresponde exteriorizar; y de ahí también, por ejemplo, que un prematuro exceso devocional dentro de la Conciencia de Krisna o una invasión corporal del Espíritu Santo no prevista o "espontánea" pueda generar sensación de singularidad o excepcionalidad). De hecho, como se desprende de cuestiones ya apuntadas, la misma conversión viene mecanizada por programas pautados y ritualizados de aprendizaje doctrinal y corporal que van encauzando un habitus de vida basado en la devoción y la disciplina religiosa. Y en ese contexto parece que debe entenderse también toda idiosincrasia experiencial individual.

\section{DOMESTICACIÓN Y CUERPOS MÍSTICOS}

El modelo institucional es, pues, el modelo de muchas cosas. Porque, en última instancia, el cuerpo que busca y consigue recibir la iniciación o el bautismo no es un cuerpo cualquiera. No puede serlo. Al contrario: debe estar preparado, debe demostrar unas condiciones o aptitudes correctas y finalmente amoldarse al prototipo de cuerpo místico que proporcionan y esperan las organizaciones de los respectivos movimientos religiosos. Desde una perspectiva material, el cuerpo debe ser domesticado conforme a las necesidades y condiciones del orden de la estructura. Así, el del sujeto adscrito o converso es un cuerpo de pureza y de virtud, que trabaja espiri- 
tualmente dentro de un campo diferencial, separado del mundo profano en los rasgos esenciales que definen el dominio de lo estructurante religioso o de la comunidad religiosa. Es un cuerpo muy individual cuyo sentido religioso implica, sin embargo, que sobre todo tome sentido junto a otros cuerpos individuales inmersos en la misma dinámica de la acción práctica y ritual, es decir, proyectándose hacia lo grupal e integrándose en la efervescencia colectiva.

La utopía y los bienes simbólicos de salvación son metas a la vista y disponibles, tanto entre los Hare Krisna, como entre los pentecostales. Unos y otros ven en este mundo un lugar de sufrimiento del que hay que liberarse, y para ello debe primar el buen comportamiento y la responsabilidad personal. Los Hare Krisna creen que el objetivo de las almas es evitar regresar a este "mundo material", proclive a la acumulación de actividad corporal generadora de karma negativo; y también que, como resultado de la buena conducta, el tiempo transcurrido en este mundo será recompensado con la eternidad espiritual, momento en que las almas individuales se fusionarán con Krisna. Para los creyentes evangélicos, la oferta de salvación en el reino de Dios después de la discriminación humana según la fe y las conductas es la otra meta disponible más elevada a nivel personal ${ }^{21}$.

${ }^{21}$ El cuerpo físico mortal (efímero) y sujeto a una ley de actividad material opuesta a la verdadera Ley, la Ley espiritual, puede ser, en efecto, un grave impedimento para la salvación: "Porque sabemos que la Ley es espiritual, pero yo soy carnal, vendido por esclavo al pecado / Pero siento otra ley en mis miembros que repugna a la ley de mi mente y me encadena a la ley del pecado, que está en mis miembros / ¡Desdichado de mi! ¿Quién me liberará de este cuerpo de muerte? / Gracias a Dios, por Jesucristo nuestro Señor... Así pues, yo mismo, que con la mente sirvo a la ley de Dios, sirvo con la carne a la ley del pecado" (Rom. 7. 22, 23, 24, 25) (Nácar y Colunga 1973: 1426). De modo semejante, el Bhagavad-Gita (5. 14, 19) distingue entre una "naturaleza superior" de la entidad viviente, identificada con Dios y con el plano mental y de la conciencia y una "naturaleza inferior", ligada a la materia y a la ley del karma, que impide liberarse del ciclo (samsara) de nacimientos y renacimientos en este mundo material: "El cuerpo material o la morada material que [la entidad viviente] obtiene, es la causa de una variedad de actividades y sus reacciones resultantes. Al vivir en semejante atmósfera condicional, si (por ignorancia) uno se identifica con el cuerpo, uno sufre los resultados de las actividades del cuerpo. Es una ignorancia adquirida desde tiempo inmemorial lo que causa la congoja y el sufrimiento físico. Tan pronto como la entidad viviente se aparta de las actividades del cuerpo se libera también de las reacciones. Mientras ella se encuentra en la ciudad del cuerpo, parece ser la ama de él, pero de hecho ni es la propietaria del cuerpo, ni la controladora de las acciones y reacciones de dicho cuerpo [...] Mientras uno se identifique con este cuerpo, se lo considera un alma condicionada, pero en cuanto se eleva a la etapa de la ecuanimidad a través de la perfecta comprensión del ser, se libera de la vida condicionada. En otras palabras, uno deja de estar sujeto a nacer en el mundo material, y, en vez de ello, puede entrar en el cielo espiritual después de su muerte" (Bhaktivedanta Swami Prabhupada 1984: 277-278, 283-284). 
En ambos sistemas, asimismo, una cuestión muy importante es confraternizar con los demás hermanos y hermanas espirituales o bien asociarse sobre todo con otros devotos o devotas. Esto sirve para delimitar simbólicamente bien la comunidad de referencia y aglutinar los vínculos en su interior de forma prioritaria, aunque ni mucho menos exclusiva. Entendiendo la esencia colectiva que exige todo movimiento, hay que asumir el servicio para la comunidad, tratar de ayudar a los correligionarios que lo necesitan, evangelizar todos juntos, realizar eventos aglutinantes, abstinencias grupales, cantos y bailes conjuntos, dejarse reconocer y valorar por el resto, también dejarse vigilar y controlar por los demás, etc. Dentro de este ámbito interactivo suele suceder, entonces, que la heterogeneidad de situaciones personales-corporales que albergan los grupos religiosos en cuestión tiende a ser en gran medida unificada por la comunidad. Una unificación forjada bajo patrones claros y precisos de expresión y de comportamiento individual y relacional. En realidad, estos procesos no son novedosos ni únicos de la religión. De acuerdo a los planteamientos libertarios de Michel Onfray para los procesos políticos, se puede concluir en un sentido más amplio que:

No sólo las francas utopías, sino también los proyectos de sociedad que han pretendido basarse en la ciencia, la positividad, el más sobrio utilitarismo, han propuesto este axioma: es necesario destruir el individuo, reciclarlo, integrarlo en una comunidad proveedora de sentido. Todas las teorías del contrato social se apoyan en esta lógica: fin del ser indivisible, abandono del cuerpo propio y advenimiento del cuerpo social, único al que en adelante se permite reivindicar la indivisibilidad y la unidad que habitualmente se asocian al individuo (Onfray 2011: 40).

Anteriormente, ya planteé la hipótesis de que en ambos sistemas los sujetos viven intensamente la religión y los símbolos religiosos, en definitiva, porque la estructura les enseña de forma sistemática y con escaso margen para la duda la forma de vivirla y de vivirlos. La manera en que lo deben explicar todo y practicar todo por medio de una serie de técnicas corporales disponibles (Cf. Vallverdú 2010). Este aprendizaje incluye asumir una concreta disposición de los cuerpos masculinos y femeninos, en ese sentido, separados espacialmente por la mitad durante los cultos o cuando existe convivencia comunitaria, a partir de las diferentes ocupaciones funcionales y los cargos organizativos por géneros, ceñidos a los mencionados rigorismos de la vestimenta y estética corporal y vinculados invariablemente a la exposición tanto privada o in-group como pública o out-group, con una performance dramatúrgica bien planeada y elaborada. El aprendizaje comprende, asimismo, la aceptación del carisma-en-su-cuerpo, del modelo corporal (mayoritariamente masculino) que encarnan los pastores o líderes máximos pentecostales, o bien los maestros espirituales entre los 
Hare Krisna. Se trata de un cuerpo carismático al que rendirse, tanto en términos de aceptación jerárquica como de ejemplo a seguir de estabilidad y ecuanimidad para el progreso espiritual personal.

En las rutinas ceremoniales de los cuerpos místicos pentecostales o Hare Krisna los sentidos son agentes activos y creativos. Dentro de la estructura, son acción y praxis por excelencia, no especialmente contemplativos. Los sentimientos están por encima de la racionalización, aunque ésta sea también necesaria como garantía de convencimiento y objetivación. Las ceremonias exigen sentimientos intensos a los sujetos, afectividad, y ellos suelen y deben responder positivamente a dicha petición. Los cultos disparan la construcción de emociones colectivamente previstas e individualmente expresadas, en forma de música rítmica, cantos espirituales y bailes que ambientan y refuerzan los vínculos grupales.

Las técnicas corporales como métodos biológicos de entrar en comunicación y comunicación con Dios según Mauss, se ven reflejadas en ambos sistemas religiosos y sus prácticas (embodied). Puede ser ilustrativo el símil automovilístico: hay que estar capacitado para conducir el cuerpo, ser hábil, acreditarse en el correcto conocimiento y dominio del vehículo, conociendo las señales que guían la conducción, las vías a seguir, los sentidos, los contrasentidos y los cambios de sentido, y también, por supuesto, las penalizaciones de la mala o imprudente conducción.

El uso de estas técnicas corporales es, además, diverso y se plasma en diferentes situaciones rituales - grupales o individuales- dentro de ambos sistemas. Puede verse con intensidad, por ejemplo, en los «avivamientos" pentecostales, ceremonias extáticas donde se considera posible el descenso del Espíritu sobre los hermanos y hermanas; o en los harinamas, cantos colectivos del mantra Hare Krisna. Son técnicas, en cualquier caso, aprendidas y coherentes con las respectivas creencias religiosas: sea el advenimiento del Espíritu Santo y el derrame de sus dones o gracias sobre los fieles en el caso pentecostal, sea el canto de los "Santos nombres" de Dios como instrumento exquisito de purificación y realización en la Conciencia de Krisna.

Los cuerpos místicos, por último, son inseparables de la memoria en los mecanismos de la construcción simbólica. Todos los procesos corporales descritos remiten a ella y, de acuerdo a Bourdieu, el concepto de "memoria incorporada" alude precisamente al cuerpo en tanto depósito donde sedimentan y se reconstruyen las memorias individuales y colectivas. En este ámbito, los Hare Krisna y los pentecostales recuperan, en efecto, dicho depósito corporal para elaborar sus discursos y relatos biográficos y de conversión, en un proceso sistemático de selección narrativa (de memoria selectiva) que acaba reflejando más que la propia experiencia real el pa- 
trón normativo e ideológico de la estructura ${ }^{22}$. En suma, con la conversión el cuerpo se convierte en el lugar de una nueva narración autobiográfica y del mundo. Tiene lugar una modificación de la visión del mundo personal y una reescritura de la realidad sobre el cuerpo, orientándolo hacia nuevas coordenadas de comportamiento y racionalización.

\section{INTERACCIONES, TIEMPOS Y ESPACIOS}

Por último, me interesa tratar los procesos de interacción, siempre significativos en términos de identidad, representación y experiencia (Goffman 1989; 1994; 2006) —y por lo tanto, en términos corporales. Dentro del ámbito en que nos movemos, por una parte, se pueden distinguir las interacciones que se establecen entre lo divino y lo humano, y por otra, muy cercana a la anterior, entre los mismos sujetos envueltos en una situación de interdependencia religiosa. Antes he apuntado la obvia importancia del aspecto colectivo dentro de ambos sistemas a diferentes niveles, pero ahora voy a insistir en el mismo por referencia a espacios y tiempos comunitarios.

Primero, cabe hablar del rol divino y del rol del creyente-practicante en mutua relación de interdependencia y reciprocidad de donaciones (Mauss 2009): el devoto o el hermano buscan y eventualmente encuentran lo divino, pero deben buscar bien para encontrar. Lograr que el Espíritu Santo descienda y beneficie a los fieles presupone primero darle amor, solicitar su presencia, atraerlo hacia uno mismo y ofrecerle el propio cuerpo como aposento simbólico. De forma semejante, rendirse y glorificar con la máxima devoción a Krisna significará también recibir sus gracias en devolución, ser reconfortado y agraciado con su misericordia. A tal fin, por ejemplo, el fuego de la adoración (con lámpara de ghee, aceite) se acerca después a la frente de los participantes en el culto, la comida sagrada (maba-prasada) ofrecida a Krisna llega también a ellos para ser consumida en forma de "remanente" divino, etc.

Dentro de este esquema de vinculación, comunicación e intercambio humano con lo divino cabe señalar, sin embargo, una diferencia significativa respecto a la representación material o física de lo simbólico en el mar-

${ }^{22}$ No obstante, las experiencias reales y motivadoras para la conversión religiosa existen. Entre ellas, una vez filtradas las reconstrucciones biográficas, parecen destacar la enfermedad (propia o de alguien cercano) en el caso del Pentecostalismo y, entre otras opciones vitales, el vegetarianismo en el caso de Hare Krisna (Cf. Vallverdú 2004). Ambas experiencias siguen ligadas a la corporeidad, por alusión a la salud en un sentido concreto o al reequilibrio bio-psico-social si se les quiere dar un sentido más dilatado. 
co de la común creencia monoteísta de ambos sistemas religiosos. Porque, en efecto, dicha creencia, proyectada de forma trinitaria en el Pentecostalismo o esencialmente binaria (Radha-Krisna) en el sistema de la Conciencia de Krisna, no tiene igual simetría en el tema de la presencia, visibilidad y relación corporal con las representaciones o imágenes de lo divino. En el caso Hare Krisna, la tradición personalista vaisnava da pie a esa pauta de forma tan marcada como minuciosa a nivel ritual. La tradición protestante en la que se encuadra el sistema pentecostal, en cambio, no alienta tal prioridad.

En efecto, en los cultos pentecostales resalta la ausencia de imágenes sagradas. El ritual excluye la representación iconográfica de los recursos sobrenaturales disponibles dentro de la tradición cristiana. Un ritual y una simbología en acción que en este sentido no necesitan soportes materiales para que los participantes perciban y experimenten lo sagrado. Teológicamente hablando, la ausencia de imágenes alusivas a Dios Padre o Jesucristo es debida a tres factores fundamentales: a) Fuimos creados a imagen y semejanza de Dios, b) El segundo mandamiento de la llamada Ley de Moisés (Éxodo 20. 3) proscribe el uso de imágenes representativas de Dios, ya que si el hombre es imagen y semejanza del creador no tiene una forma representativa y c) El hombre, al ser una persona espiritual, cuando representa a Dios en imágenes, le asigna una valoración carnal o terrenal, situación que contraría el carácter etéreo de Yavhé (García, Ángel y Colina $2010)^{23}$.

Como explica Daniel Chiquete (2007), la negación absoluta de imágenes en el Pentecostalismo se explicaría en la actualidad por el hecho práctico de buscar su contraposición, o incluso su oposición simbólica, respecto a las representaciones católicas, sean la iglesia institucional o bien el catolicismo popular. Además de la importancia de la palabra, rasgo de herencia protestante, en el Pentecostalismo la experiencia subjetiva del encuen-

${ }^{23}$ Dentro de la gran tradición protestante, ya Calvino se posicionó en contra, tanto de la adoración, como de la fabricación de imágenes. Para él Dios es Espíritu y debe ser adorado en Espíritu; el único reflejo de Dios que reconoce es la Palabra. Lutero, por su parte, afirmará que lo que sucede en las iglesias es que el Señor habla a los fieles por medio de su Palabra y que éstos, por su parte, hablan con él por medio de la oración y la alabanza; sin más mecanismos intermedios. Por ello, desde este momento, las imágenes religiosas en los templos empiezan a no ser tomadas en consideración. Igualmente la Reforma remarcó la idea central de la comunidad en la celebración litúrgica, tal como atestigua la misma disposición de los espacios en el interior de las iglesias. También la prédica, expuesta en el idioma propio de las comunidades, se convierte en uno de los momentos más relevantes. En suma, la imagen queda desplazada por la palabra durante la celebración cristiana, de modo que oír se vuelve más importante que ver (Chiquete 2007). 
tro con el Espíritu Santo recibe la máxima prioridad. Y en este contexto la imagen no tiene mucha cabida. Chiquete considera esta situación como «una expresión iconoclasta pasiva", en el sentido de que no se intenta dañar ninguna imagen, simplemente se niega su existencia. En resumidas cuentas, lo importante en el Pentecostalismo no es tanto la imagen física o pictórica sino la imagen verbal, y el templo objetivo de ladrillo y cemento es cambiado por el subjetivo de la comunidad como morada del Espíritu Santo.

En el sistema de la Conciencia de Krisna, por el contrario, las figuras físicas de la deidad (Dios, Krisna) y de su consorte (Radha), así como también de las demás imágenes principales del panteón vaisnava y la escultura del maestro espiritual Bhaktivedanta Swami, son material imprescindible dentro de los templos o a nivel privado. Son figuras a las que se mira, se toca, se viste, se perfuma, se adora... Las representaciones iconográficas, sea en el altar, en libros, fotografías, postales... son muy importantes en cualquier situación ritual u ordinaria. Estimulan la percepción y la acción espiritual. Sirven para que devotos y devotas se hagan la conveniente idea físi$\mathrm{ca} / \mathrm{material} /$ corpórea de lo divino y para que entiendan que deben volcar todos sus esfuerzos y sentidos hacia la devoción espiritual. Los elementos visibles y palpables vuelven a ser decisivos para animar la acción práctica y simbólica ${ }^{24}$.

En el caso de los Hare Krisna, el contacto físico con las divinidades requiere muy obviamente una absoluta purificación de los sacerdotes (brabmanas) que poseen un grado iniciático superior y son los especialistas reconocidos para operar a ese nivel. En términos teológicos la explicación es siempre plausible, pero en términos de praxis y aprendizaje de las técnicas místico-corporales esa explicación puede evocar una lógica material subyacente y tiene que ver con la construcción del dualismo tradicional cuerpo-alma. La autonegación del cuerpo social que también he apuntado antes se compensa con la afirmación del cuerpo místico personal, liberado (o en camino de liberación) de su tendencia inherente al pecado. Con todo, el cuerpo bajo control o "restringido" — como los pentecostales tienen muy claro- puede llegar a ser un templo de Dios.

En el "mundo material" Hare Krisna o en el "mundo-mundano" del Pentecostalismo el alma no aparece, sí en cambio el cuerpo como "carne"

${ }^{24}$ A modo de apunte complementario: Sucede que incluso en importantes sistemas no teístas, como el budismo, por ejemplo en su variante tántrica, suelen necesitarse imágenes físicas para activar los estados de visualización y meditación que exigen las prácticas religiosas. No obstante, otro rasgo común que parece significativo en este sentido es que en el tantrismo los sentimientos sensuales-corporales implícitos en los procesos simbólico-espirituales son también particularmente acentuados. 
(recuperando a Bryan Turner) y su conducta disoluta y pecaminosa. El alma aparece y resalta allí donde es explícitamente útil, en el terreno de lo extra-empírico y para oponerse a lo empírico. Pero, a la vez, alude a la verdadera identidad de los devotos o hermanos, que la hacen valer como medio de acceso a la divinidad a través de un lenguaje explícito o por medio de una comunicación sumamente intimista y no verbalizada. El cuerpo material es el vehículo que no queda más remedio que conducir en este mundo, pero la conciencia del alma (del ser como alma) lo convierte en cuerpo espiritual tras el debido proceso de descontaminación o purificación, y de ahí, en el mejor de los casos, se abre la vía hacia la salvación o liberación eternas ${ }^{25}$.

En definitiva, el acceso íntimo a la divinidad implica intercambio de dones y es mediatizado por el cuerpo en ambos sistemas, con alabanzas, oraciones, mantras, glorificaciones... Todas ellas dando lugar a la interacción de sujetos participantes dentro del espacio o de los espacios rituales disponibles, sean éstos la "iglesia" pentecostal ${ }^{26}$, el templo Hare Krisna u otros más privados. Y dentro, igualmente, de un tiempo determinado o tiempos varios. Existen, en efecto, unos espacios y unos tiempos disponibles, pero a la vez bien delimitados, para la interacción y la unificación social y también, en particular, para el éxtasis místico. Espacios y tiempos que, desde un enfoque colectivo, están bajo un control carismático legitimado y con-

${ }^{25}$ En la Biblia aparece un serio aviso a "los que caminan según la carne": "Y si el Espíritu de aquel que resucitó de entre los muertos habita en vosotros, el que resucitó a Cristo Jesús de entre los muertos dará también vida a vuestros cuerpos mortales por virtud de su Espíritu, que habita en vosotros / Así pues, hermanos, no somos deudores a la carne de vivir según la carne / Que si vivís según la carne, moriréis; más, si con el espíritu mortificáis las obras del cuerpo, viviréis" (Rom. 8. 11, 12, 13) (Nácar y Colunga 1973: 1426-1427). En el Bhagavad-Gita, por su parte, se encuentran muchísimas referencias al dualismo cuerpo-alma o cuerpo-espíritu, así como al camino para conseguir ser un "devoto puro" de Krisna, que empieza su recorrido con la autoconciencia del cuerpo espiritual: "Para el cuerpo espiritual no hay nacimiento, muerte, vejez ni enfermedades, así que aquel que consigue un cuerpo espiritual, que se vuelve uno de los asociados de la Suprema Personalidad de Dios y que se dedica al servicio devocional eterno, verdaderamente está liberado" (B.-G., 7. 29) (Bhaktivedanta Swami Prabhupada 1984: 389-390).

${ }^{26}$ Cierto es que el término "iglesia" no alude necesariamente en este caso a una estructura con techo y cuatro paredes, sino a un lugar o espacio donde, sin más pretensiones, se puedan reunir los fieles, a la congregación de los hermanos de fe. García, Ángel y Colina (2010: 89) añaden algo que serviría igualmente para el templo de los Hare Krisna: "Es el espacio donde se produce la communitas y donde se propicia el despliegue de emociones que consagran el realce de la espiritualidad de los individuos cohesionados con el fin común". 
forman un ambiente protector, donde uno siente que puede "dejarse ir" o "dejarse diluir" en el grupo para luego "volver" a la inevitable gestión individual. "Dejarse ir" o "dejarse diluir" en el seno de una comunidad donde uno se siente integrado; "Volver" a la individualidad con la mente puesta, con todo, en asegurar que lo que uno hace no entra en contradicción con el grupo mientras exista vinculación sincera y honesta - cuestión al final de conciencia y responsabilidad que vuelve a poner a la estructura en el punto de mira.

De acuerdo a esas dinámicas de unificación general en torno a un consenso simbólico de comunidad, los cuerpos místicos y políticos que se han tratado son otra prueba de que — como sugería Victor Turner- la communitas tiende a encaminar a sus integrantes desde el principio hacia la estructura. De cualquier modo, la ebullición corporal y sentimental, o simplemente el reconocimiento del cuerpo y de las emociones dentro de un grupo organizado, son aspectos altamente significativos cuando se trata de examinar e interpretar acciones e interacciones desde la óptica de los sujetos. Con todo, en sus diferentes contextos históricos-sociales y particulares estructuras de expresión religiosa, dichas experiencias y prácticas, a pesar de proyectar un fondo espiritual, parecen resaltar más que nada la obsesión por las cosas materiales, terrenales y de este mundo empírico.

\section{BIBLIOGRAFÍA CITADA}

Althusser, L. 1998. "Ideology and Ideological State Apparatuses", en J. Storey (ed.) Cultural Theory and Popular Culture. A Reader: 153-164. Harlow: Prentice Hall.

Bhaktivedanta Swami Prabhupada, A. C. 1982. El libro de Krisna / Krisna. La Suprema Personalidad de Dios. Madrid: Fondo Editorial Bhaktivedanta.

Bhaktivedanta Swami Prabhupada, A. C. 1984. El Bhagavad-Gita. Tal como es. Barcelona: The Bhaktivedanta Book Trust.

Bhaktivedanta Swami Prabhupada, A. C. 1990. Srimad Bhagavatam de Krsna-Dvaipayana Vyasa. Canto cuarto: La creación de la cuarta orden. Parte primera. Barcelona: The Bhaktivedanta Book Trust España.

Bourdieu, P. 1971. "Gènese et structure du champ religieux". Revue Française de Sociologie XII: 295-334.

Bourdieu, P. 1996. Cosas dichas. Barcelona: Gedisa.

Bourdieu, P. 2008. El sentido práctico. Madrid: Siglo XXI.

Bourdieu, P. 2009. La eficacia simbólica. Religión y política. Buenos Aires: Biblos.

Campiche, R. J. 1996. "Introduction", Social Compass 43 (1): 4-6.

Chiquete, D. 2007. "Algunas raíces teológicas e históricas de la iconoclasia protestante y pentecostal", en Consejo Latinoamericano de Iglesias, V Asamblea General. Buenos Aires, 19-25 de febrero.

Delgado, M. 1998. Diversitat i integració. Barcelona: Empúries. 
Dimock, Jr. E. C. 1966a. "Doctrine and practice among the vaisnavas of Bengal", en M. Singer (ed.), Krishna: Myths, Rites and Attitudes: 41-63. Chicago: The University of Chicago Press.

Dimock, Jr., E. C. 1966b. The Place of the Hidden Moon. Erotic Mysticism in the VaisnavaSabajiya Cult of Bengal. Chicago: The University of Chicago Press.

Douglas, M. 1991. Pureza y peligro. Un análisis de los conceptos de contaminación y Tabú. Madrid: Siglo XXI.

Durkheim, E. 1982. Las formas elementales de la vida religiosa. Madrid: Akal.

Fernandez, J. 1965. "Symbolic Consensus in a Fang Reformative Cult". American Anthropologist 67 (4): 902-929.

Foucault, M. 1992. Microfísica del poder. Madrid: La Piqueta.

García Delgado, J., M. E. Ángel y A. Colina. 2010. "Cultos de oración y 'don de lenguas' en grupos pentecostales en Maracaibo". Opción 61: 94-97.

Garma, C. 1998. "The Socialization of the Gifts of Tongues and Healing in Mexican Pentecostalism". Journal of Contemporary Religion 13 (3): 353-361.

Goffman, E. 1989. Estigma. La identidad deteriorada. Buenos Aires: Amorrortu.

Goffman, E. 1994. La presentación de la persona en la vida cotidiana. Buenos Aires: Amorrortu.

Goffman, E. 2006. Frame Analysis. Los marcos de la experiencia. Madrid: CIS.

Goodman, F. 1972. Speaking in Tongues. A Cross-Cultural Syudy of Glossolalia. The University of Chicago Press.

Hopkins, Th. J. 1966. "The Social Teaching of the Bhagavata Purana", en M. Singer (ed.), Krishna: Myths, Rites and Attitudes: 3-22. Chicago: The University of Chicago Press.

Hutch, R. A. 1980. "The Personal Ritual of Glossolalia". Journal for the Scientific Study of Religion 19 (3): 255-266.

Jaquith, J. R. 1967. "Toward a Typology of Formal Communicative Behaviors". Anthropological Linguistics 9 (1): 1-8.

Lacan, J. 1981. Escritos, I y II, México: Siglo XXI.

Martínez, A. T. 2009. "Introducción. Religión y creencias en el trabajo sociológico de Pierre Bourdieu", en P. Bourdieu, La eficacia simbólica. Religión y política: 9-40. Buenos Aires: Editorial Biblos.

Mauss, M. 1991. "Técnicas y movimientos corporales", en Sociología y antropología: 337356. Madrid: Tecnos.

Mauss, M. 2009. Ensayo sobre el don. Forma y función del intercambio en las sociedades arcaicas. Madrid: Katz Editores.

May, L. C. 1956. "A Survey of Glossolalia and Related Phenomena in Non-Christian Religions". American Anthropological Association 1-6 (58): 75-96.

Menéndez, E. 2000. "La dimensión antropológica". Contextos, sujetos y drogas. Un manual sobre drogodependencias. Barcelona: Fundación de Ayuda contra la drogadicción /Ayuntamiento de Barcelona/Instituto Municipal de Salud Pública.

Merleau-Ponty, M. 2000. Fenomenología de la percepción. Barcelona: Península.

Nácar, E. y A. Colunga. 1973. Sagrada Biblia. Versión directa de las lenguas originales. Madrid: Biblioteca de autores cristianos.

Onfray, M. 2011. Politica del rebelde. Tratado de resistencia e insumisión. Barcelona: Anagrama.

Scheper-Hughes, N. y M. Lock. 1987. "The Mindful Body: A Prolegomenon to Future Work in Medical Anthropology". Medical Anthropology Quaterly 1 (1): 6-41. 
Turner, B. S. 1989. El cuerpo y la sociedad. Exploraciones en teoría social. México: Fondo de Cultura Económica.

Turner, B. S. 1994. Regulating bodies. Essays in Medical Sociology. Londres y Nueva York: Rouledge.

Turner, B. S. 1997. La religión y la teoría social. Una perspectiva materialista. México: Fondo de Cultura Económica.

Turner, V. 1988. El proceso ritual. Estructura y antiestructura. Madrid: Taurus.

Vallverdú, J. 1999. "Conversión, compromiso y construcción de identidad en el movimiento Hare Krisna". Alteridades 9 (18): 57-70.

Vallverdú, J. 2001. El cant de la devoció. Un estudi antropològic sobre el Hare Krisna. Tarragona: Arola.

Vallverdú, J. 2004. "Els negatius de la memòria: les vides (re)compensades". Revista d'Etnologia de Catalunya 23: 70-81.

Vallverdú, J. 2008. Las lenguas del Espíritu. Religiones carismáticas y pentecostalismo en México. Tarragona: Publicacions URV.

Vallverdú, J. 2009a. "Mi cuerpo es un templo de Dios'. Carisma y emoción en los sistemas religiosos". Iztapalapa 62: 135-154.

Vallverdú, J. 2009b. “¿Vuelve el Espíritu Santo? Dinámicas de la emoción religiosa y el trance extático en el cristianismo carismáticon, en J. Martí y Y. Aixelà (eds.), El cuerpo: Objeto y sujeto de las Ciencias Humanas y Sociales. Barcelona: CSIC, 28-31 de enero.

Vallverdú, J. 2010. "Cossos místics, cossos polítics: el control material de l'experiència religiosa al moviment Hare Krisna". Quaderns de l'Institut Català d'Antropologia 26: $17-40$.

Wacquant, L. 1995. "Introducción", en P. Bourdieu y L. Wacquant, Respuestas. Por una antropología reflexiva: 15-38. México: Grijalbo.

Wilson, B. 1970. "Los movimientos pentecostales". Sociología de las sectas religiosas: 6692. Madrid: Guadarrama.

Fecha de recepción: 27 de septiembre de 2011

Fecha de aceptación: 25 de enero de 2012 